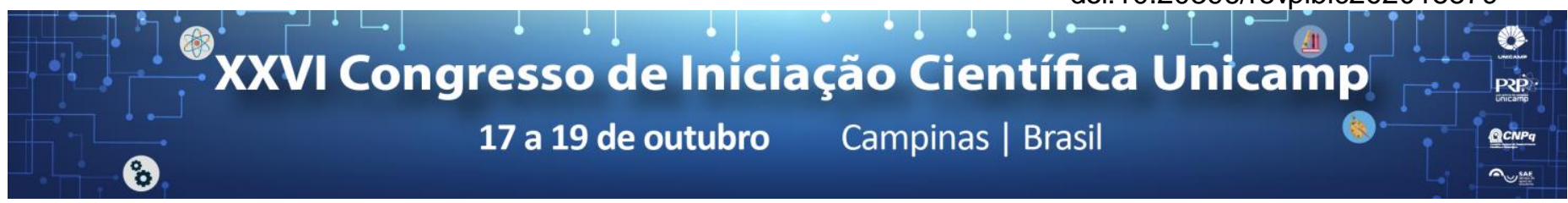

\title{
Technical potential for the use of landfill biogas in the replacement of fossil fuel in the urban transport of the Administrative Region of Campinas
}

\author{
Lucas C. Souza*, Mauro D. Berni
}

\begin{abstract}
This research analyzes the use of biomethane, obtained from biogas generated by anaerobic digestion in landfills, as an alternative to diesel oil in the means of transportation of the administrative region of Campinas (RAC). With data bases and statistics information, the consumption of diesel on transportation in the region, and also waste production, were determined. It was obtained that the wastes generates 1.24 million cubic meters of biomethane per day, reflecting in 3.04 TWh of energy potential in the year. These values result in a $16.7 \%$ Diesel fleet replacement, resulting in $8.22 \times 10^{\wedge} 5 \mathrm{tCO} 2$ equivalent avoided. Therefore, the results indicated a great potential of biomethane as an alternative for Diesel oil in the RAC, contributing to a low-carbon economy. However, non-compliance with Proconve emission standards creates a barrier to the use of biomethane in the country. Further discussion is needed for a sustainable equation.
\end{abstract}

\section{Key words:}

Biogas, Biomethane, Landfill.

\section{Introduction}

The constant demand for energy is directly related with the humanity development throughout history and carries a great dependence on fossil fuels. By 2025, Brazil committed to reduce its greenhouse gas (GHG) emissions by $37 \%$ and to increase the share of bioenergy in its energy matrix to $18 \%$ (Paris Agreement, NDC, 2018)). The transport sector is a major contributor to GHG emissions, and should be subject to changes to meet national GHG reduction targets.

The Administrative Region of Campinas (RAC) represents a substantial portion of the GHG emissions in São Paulo state. Also represents a substantial part of the production of Municipal Solid Waste (MSW).

In 2016, it generated 5,092 tons of MSW per day. Therefore, biomethane obtained from biogas landfill purification is an important option for the displacement of Diesel oil in the transport energy matrix of the region and corroborates the São Paulo Energy Plan 2020, which provides for the use of biogas in Diesel cycle engines.

\section{Results and Discussion}

In order to analyze the potential of biomethane as an alternative to Diesel oil in the RAC fleet, this work estimated the Diesel oil demand of the region's fleet and the biomethane energy supply of its sanitary landfills. Subsequently, it analyzed the environmental impacts resulting from this substitution in terms of avoided carbon dioxide emissions (CO2eq).

The urban fleet of RAC was characterized by analyzing statistical databases as the BEESP (2017) and Statistical Yearbook of Energy by Municipality in the State of São Paulo (2017), base year 2016.

The research verified that the region consumed, in 2016, about 1.8 billion liters of Diesel fuel for transportation, implying an energy demand of 18.22 TWh in the year.

It was also verified that the region received 5,092.6 tons of MSW per day. MSW composition was estimated by ALENCAR (2017) and using the methodology described by Tchobanoglous, Thessen \& Vigil (1993) it was possible estimate a production of 1.24 million cubic meters of biomethane per day, implying an energy supply of 3.04 TWh in the year.

Thus, it is obtained that biomethane has the potential to replace the RAC Diesel fleet by $16.7 \%$.

The environmental impacts resulting from this fact was calculated, taking into account, the avoided emissions of carbon dioxide from diesel and the methane emissions in the landfills subtracted from the emissions generated by the biomethane burning.

The balance resulted in $8.22 \times 10^{5} \mathrm{tCO}_{2} \mathrm{eq}$ potentially avoided.

\section{Conclusions}

This project shows feasible to promote environmental protection, sanitation and use of renewable energy sources with MSW.

\section{Acknowledgement}

To CNPq and PRP-UNICAMP, PIBIC program for the aid grant, NIPE for the structure and material support, to doctoral Christy W. S. Romero for help with the software ArcGis.

Paris Agreement. Disponível em: http://www.mma.gov.br/clima/convencao-dasnacoes-unidas/acordo-de-paris. Accessed 9-maio-2018.

BEESP, Balanço Energético do Estado de São Paulo 2017: Ano Base 2016, Secretaria de Energia, Série Informações Energéticas, São Paulo, 2017, 270 p.

Statistical Yearbook of Energy by Municipality in the State of São Paulo (2017), base year 2016. Secretaria de Energia e Mineração. Anuário Estatístico de Energéticos por município no Estado de São Paulo 2017, ano base 2016. São Paulo, http://www.energia.sp.gov.br/. Accessed 15-november-2017.

ALENCAR, Lívia Caldas. Porencial Bioquímico de Metano da Fração Biodegradável dos Resíduos Sólidos Urbanos de Campinas - SP. 2017. 106 f. Tese (Mestrado em Engenharia Química) - Faculdade de Engenharia Química, Universidade Estadual de Campinas, Campinas. 2017.

TCHOBANOGLOUS, G.; THEISEN, H.; VIGIL, S. (1993). Integrated Solid Waste Management. Engeneering Principles and Management Issues. Irwin MacGraw - Hill. 978p 